\title{
SPECTR System Operational Test Report
}

W. H. Landman, Jr.

The INL is a

U.S. Department of Energy

National Laboratory

operated by

Battelle Energy Alliance

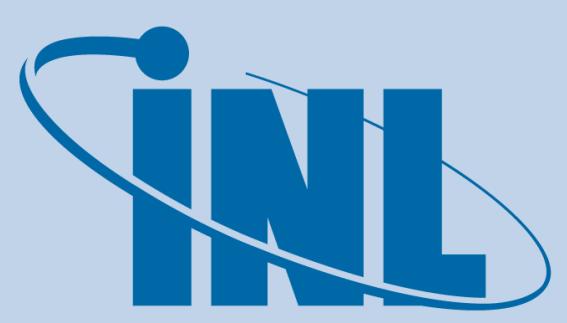

Idaho National Laboratory
August 2011

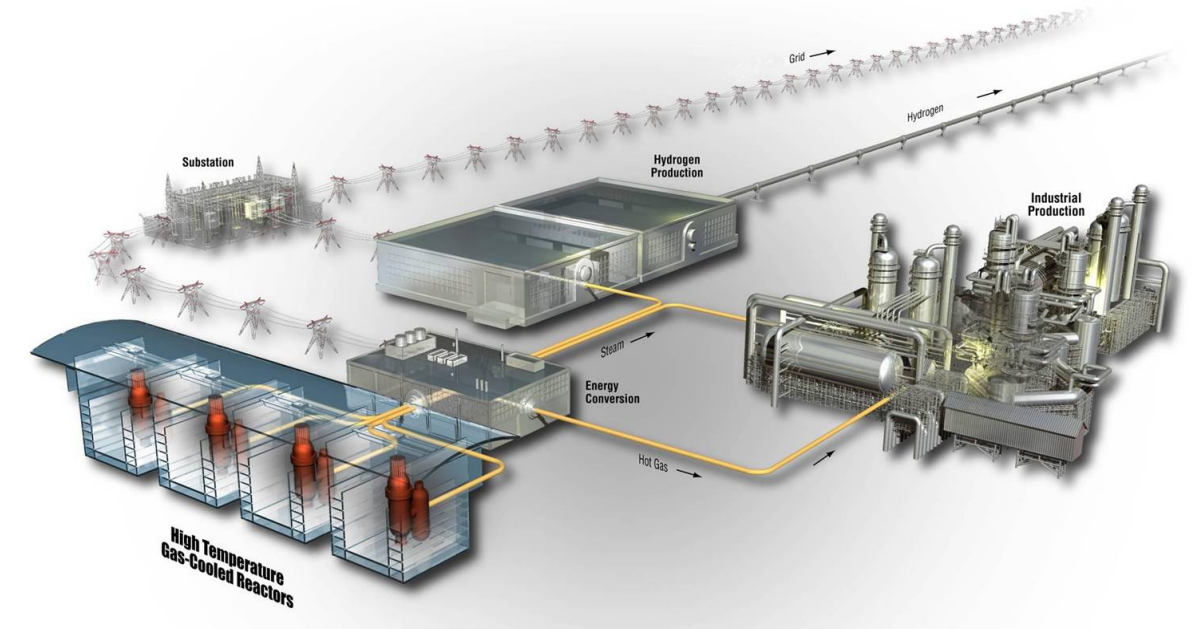




\section{DISCLAIMER}

This information was prepared as an account of work sponsored by an agency of the U.S. Government. Neither the U.S. Government nor any agency thereof, nor any of their employees, makes any warranty, expressed or implied, or assumes any legal liability or responsibility for the accuracy, completeness, or usefulness, of any information, apparatus, product, or process disclosed, or represents that its use would not infringe privately owned rights. References herein to any specific commercial product, process, or service by trade name, trade mark, manufacturer, or otherwise, does not necessarily constitute or imply its endorsement, recommendation, or favoring by the U.S. Government or any agency thereof. The views and opinions of authors expressed herein do not necessarily state or reflect those of the U.S. Government or any agency thereof. 


\title{
SPECTR System Operational Test Report
}

\author{
W. H. Landman, Jr.
}

August 2011

\begin{abstract}
Idaho National Laboratory
Next Generation Nuclear Plant Project

Idaho Falls, Idaho 83415
\end{abstract}

http://www.inl.gov

Prepared for the

U.S. Department of Energy

Office of Nuclear Energy

Under DOE Idaho Operations Office

Contract DE-AC07-05ID14517 



\title{
Next Generation Nuclear Plant Project
}

\section{SPECTR System Operational Test Report}

\author{
INL/EXT-11-22903
}

August 2011

Approved by:
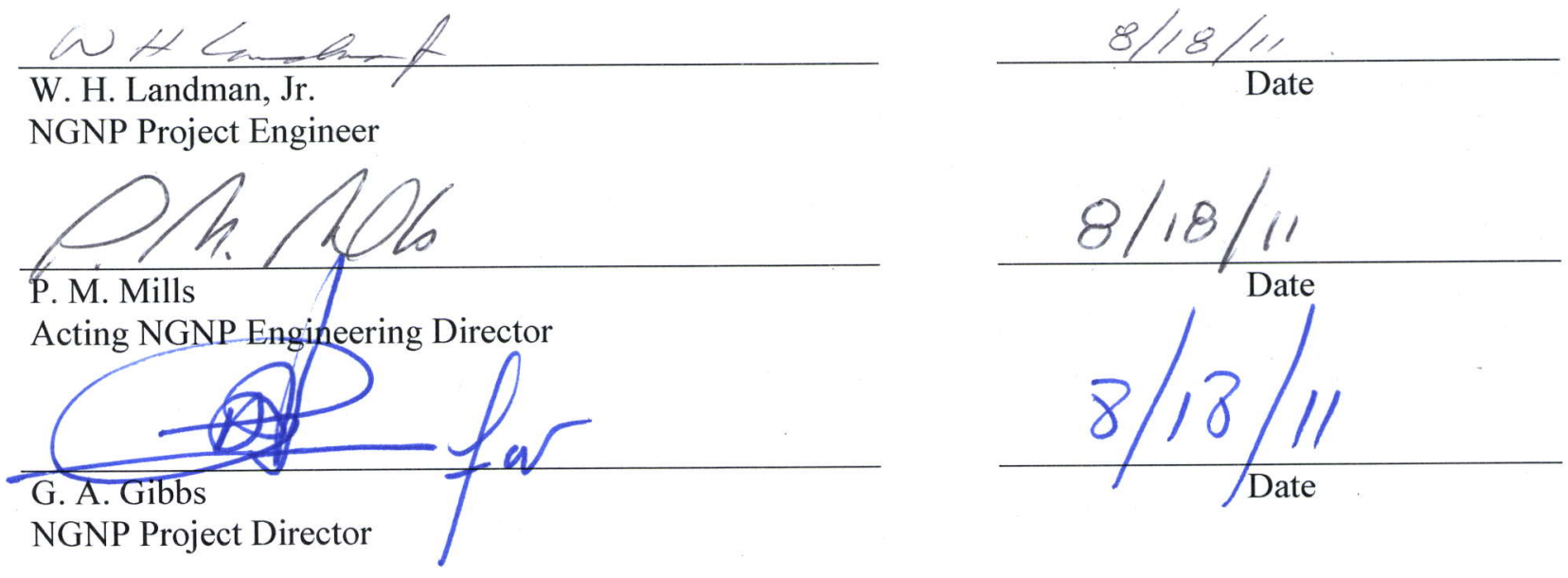



\begin{abstract}
This report overviews installation of the Small Pressure Cycling Test Rig (SPECTR) and documents the system operational testing performed to demonstrate that it meets the requirements for operations. The system operational testing involved operation of the furnace system to the design conditions and demonstration of the test article gas supply system using a simulated test article. The furnace and test article systems were demonstrated to meet the design requirements for the Next Generation Nuclear Plant. Therefore, the system is deemed acceptable and is ready for actual test article testing.
\end{abstract}




\section{SUMMARY}

The Small Pressure Cycling Test Rig (SPECTR) will be used to test mechanical components at high temperatures and pressures in support of development of fabrication methods for high temperature compact heat exchangers as well as other potential applications. SPECTR consists of a high temperature furnace (capable of operation at temperatures of up to $1200^{\circ} \mathrm{C}$ and pressures up to $1 \mathrm{MPa}$ ), the associated power transformer, furnace coolant circulation system, and controls and instrumentation, and a separate test article gas supply and exhaust system.

This report overviews the installation of the SPECTR and documents the system operational testing performed to demonstrate that the SPECTR meets the requirements for operations. System operational testing involved operation of the furnace system to the design conditions and demonstrated the test article gas supply system using a simulated test article.

The furnace and test article systems were demonstrated to meet the design requirements with the exception of reaching $1200^{\circ} \mathrm{C}$ at $150 \mathrm{psig}$ of nitrogen. However, this requirement for operation at $1200^{\circ} \mathrm{C}$ and 150 psig of nitrogen exceeds the anticipated need for testing components for the Next Generation Nuclear Plant. Therefore, the system is deemed acceptable and is ready for actual test article testing. 


\section{ACKNOWLEDGMENTS}

The author would like to acknowledge the help and support of all the team members who supported the design, procurement, installation, and startup of this small pressure cycling test rig (SPECTR). Brad Benefiel and Greg Preslar provided Engineering design, installation, and startup support. Sam Dixon coordinated the procurement efforts. Kevin DeWall was invaluable in helping to develop the Laboratory Instruction for the SPECTR system. Most importantly, the installation and startup could not have been performed as quickly and efficiently as it did without the support of Dave Swank and his team (DC Haggard and Joe Lord). 


\section{CONTENTS}

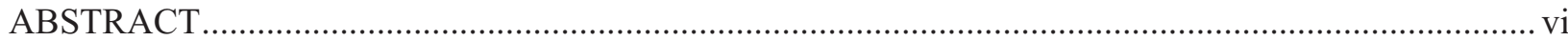

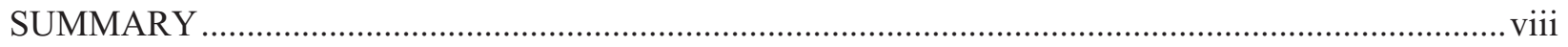

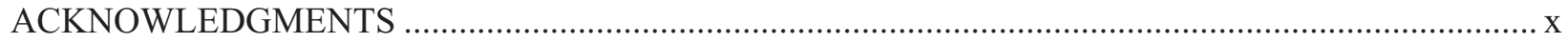

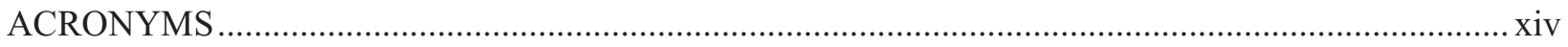

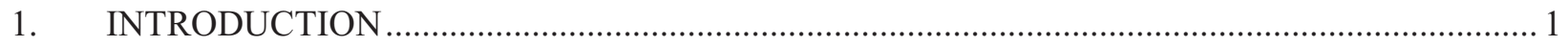

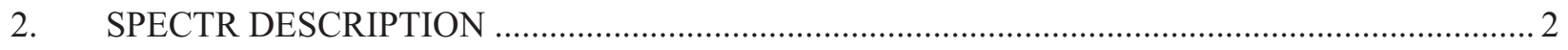

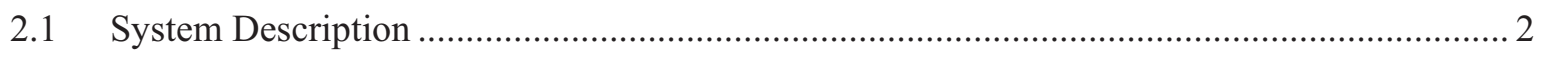

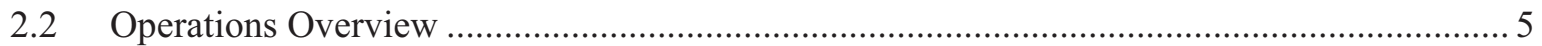

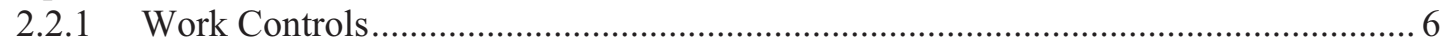

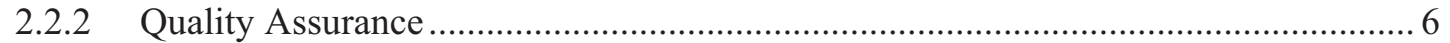

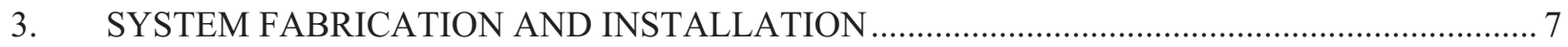

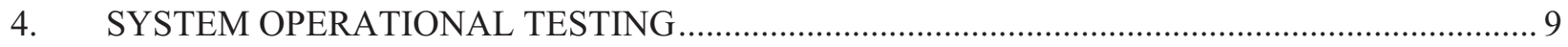

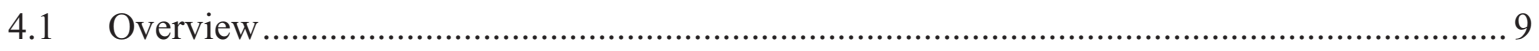

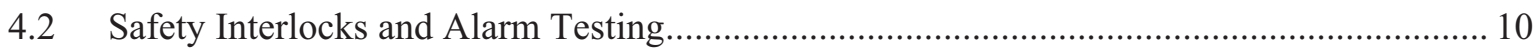

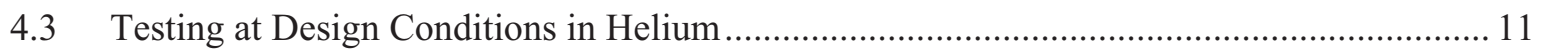

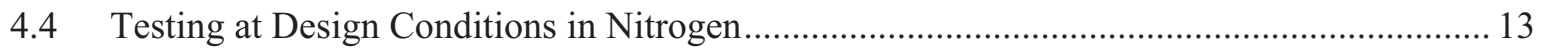

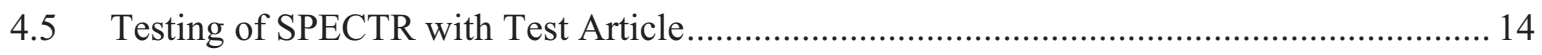

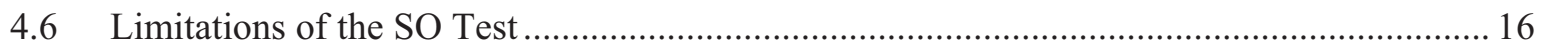

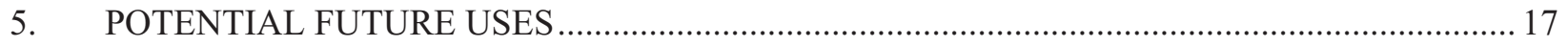

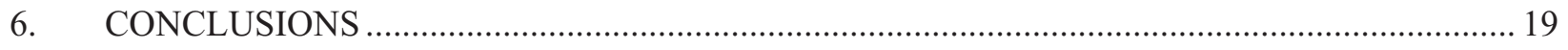

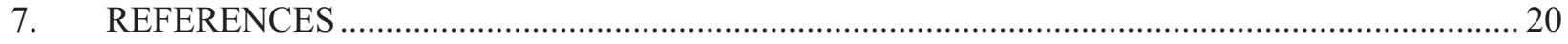

\section{FIGURES}

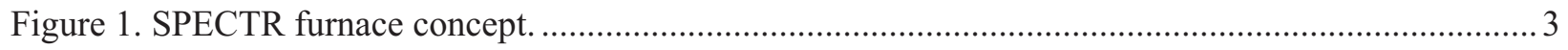

Figure 2. SPECTR Arrangement in IF-657 Bay W3 ........................................................................ 3

Figure 3. Piping and instrument diagram for the SPECTR system........................................................ 4

Figure 4. Placing the SPECTR furnace in IEDF Bay 3. ..................................................................... 7

Figure 5. SPECTR system in Bay W-3 of IEDF............................................................................. 7

Figure 6. SPECTR system viewed from inside Bay W-3 of IEDF.................................................... 8

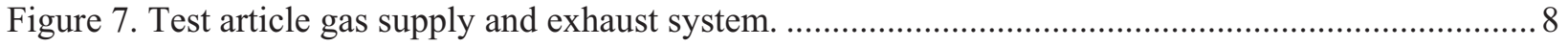

Figure 8. Main control screen for the AVS furnace system.............................................................. 9

Figure 9. Typical recipe screen from the AVS control system. ........................................................... 10 
Figure 10. Main display screen for test article control system.

Figure 11. Screen capture from $1200^{\circ} \mathrm{C}, 34 \mathrm{kPa}$ helium demonstration run. ........................................... 12

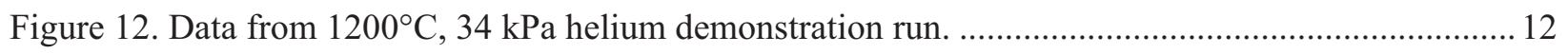

Figure 13. View of system response when the control thermocouple was changed................................ 13

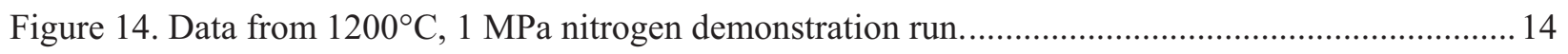

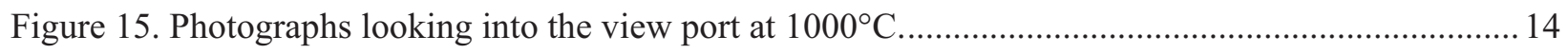

Figure 16. Furnace operation during $34 \mathrm{kPa}, 600^{\circ} \mathrm{C}$ SO test with test article. ...................................... 15

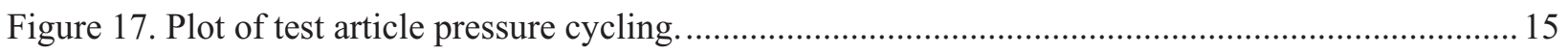

Figure 18. Progression of NGNP heat transport system from TRL-3 (proof of concept) to TRL-4

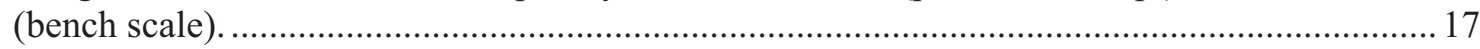




\section{ACRONYMS}

ASME American Society of Mechanical Engineers

AVS Advanced Vacuum Systems

BPV Boiler and Pressure Vessel

HMI human-machine interface

IEDF INL Engineering Demonstration Facility

IHX intermediate heat exchanger

INL Idaho National Laboratory

LI Laboratory Instruction

LWP Laboratory-wide Procedure

NGNP Next Generation Nuclear Plant

PLC programmable logic controller

QL Quality Level

QLD Quality Level Determination

SO system operational

SPECTR Small Pressure Cycling Test Rig

TRL Technology Readiness Level 


\section{SPECTR System Operational Test Report}

\section{INTRODUCTION}

The Next Generation Nuclear Plant (NGNP) will be a high temperature gas-cooled reactor that provides high temperature energy for industrial process applications and the generation of electricity. Current design concepts for the NGNP are based on a reactor outlet temperature of $750^{\circ} \mathrm{C}$, but advanced designs will operate at temperatures up to $950^{\circ} \mathrm{C}$ and pressures up to $7 \mathrm{MPa}$. Part of the NGNP Project addresses the research and development necessary to advance the Technology Readiness Levels (TRLs) of the major components of the heat transport system to commercial scale for both the current $750^{\circ} \mathrm{C}$ design as well as the future $950^{\circ} \mathrm{C}$ design.

One aspect of the development of the heat transport system is the advancement of the intermediate heat exchanger (IHX) from its current rating of TRL-3 (proof of concept) to TRL-4 (bench scale) as described by Collins (2009). That development includes testing of subassemblies of the IHX that have been fabricated using a diffusion welding technique (Mizia 2010) to assess the fatigue and creep performance of the fabricated parts.

The Small Pressure Cycling Test Rig (SPECTR) supports fatigue testing of the subassemblies at temperatures of up to $1200^{\circ} \mathrm{C}$ and test article internal pressures of up to $9 \mathrm{MPa}$. SPECTR can also be used to perform pressure testing of other test articles, such as the pressure capsule and the simplified model test device described by Wright (2010), which would provide biaxial creep data that would support development of design methods. 


\section{SPECTR DESCRIPTION}

\subsection{System Description}

SPECTR is designed to test pressurized components at temperatures up to $1200^{\circ} \mathrm{C}$. It was fabricated by Advanced Vacuum Systems (AVS) in Ayer, MA. The technical requirements are specified by Landman (2010). It can support proof pressure testing, cyclic (fatigue) pressure testing, or gas permeation testing. The SPECTR furnace concept is shown schematically in Figure 1. A general arrangement of the system is shown in Figure 2, and the piping and instrumentation diagram for the system is shown in Figure 3. The heated volume of the furnace is $3 \mathrm{ft}$ in diameter by $3 \mathrm{ft}$ long. The test articles are supported on an internal structural support of silicon carbide that is cantilevered off the chamber door. The test article(s) must fit within that volume and cannot exceed a weight limit of $150 \mathrm{lbf}$.

The system consists of a furnace chamber assembly, a cooling pump station, an air-cooled heat exchanger, a vacuum system, a furnace inert gas supply and exhaust system, and the associated electrical and control system cabinets and hardware. There is a separate gas supply and exhaust system for the test article.

The furnace chamber assembly consists of a pressure vessel that contains thermal insulation, heating elements, and supports for a test article. The furnace vessel is a jacketed, stainless steel pressure vessel designed to the requirements of Section VIII, Division 1 of the American Society of Mechanical Engineers (ASME) Boiler and Pressure Vessel (BPV) code. The design pressure of the vessel is 165 psig. The insulation and heater elements can be operated at temperatures of up to $1200^{\circ} \mathrm{C}$. The cooling jacket of the pressure vessel provides an annular space in which a cooling fluid (normally propylene glycol) is circulated. Areas of the vessel that cannot be surrounded by the jacket (such as nozzles) are provided with cooling coils. The flow rate in the cooling jacket and coils is designed to maintain the external temperature of the vessel at less than $50^{\circ} \mathrm{C}$. In the event of a loss of power, the cooling system will transfer to once-through cooling using city water.

The cooling pump station circulates the vessel coolant at a nominal flow rate of 75 gpm between the furnace and the air-cooled heat exchanger located outside of the test bay in INL facility IF-657.

The vacuum system consists of a mechanical vacuum pump, oil filter system, and the associated valves and instrumentation. The vacuum pump is capable of reducing the pressure in the vessel to less than 10 Torr. The purpose of the vacuum system is to reduce the concentration of gaseous contaminants such as oxygen and water vapor in the furnace prior to exposing the test articles to the high temperatures.

The pressure and composition of the gas in the furnace chamber is controlled by the furnace gas supply and exhaust system. The gas environment around the test article can be any inert gas. The pressure of the environmental gas can be as high as $1 \mathrm{MPa}$, although the allowable pressure will be limited by conduction of heat to the vessel and nozzles, which is a function of the gas thermal properties. Gases that have high thermal conductivities and heat capacities, such as helium, would be limited to lower pressures. Operation of the furnace with a helium environment at $1200^{\circ} \mathrm{C}$ and $34 \mathrm{kPa}$ and a nitrogen environment at $1200^{\circ} \mathrm{C}$ and $1 \mathrm{MPa}$ was demonstrated at the factory acceptance test.

The furnace is controlled by an AVS-supplied Allen-Bradley programmable logic controller (PLC). The PLC controls the heat-up rate and temperature of the furnace, the pressurization rate and pressure of the furnace, startup and shutdown of the coolant circulation and vacuum systems, and provides alarms and automatic actions in the event of off-normal conditions. 


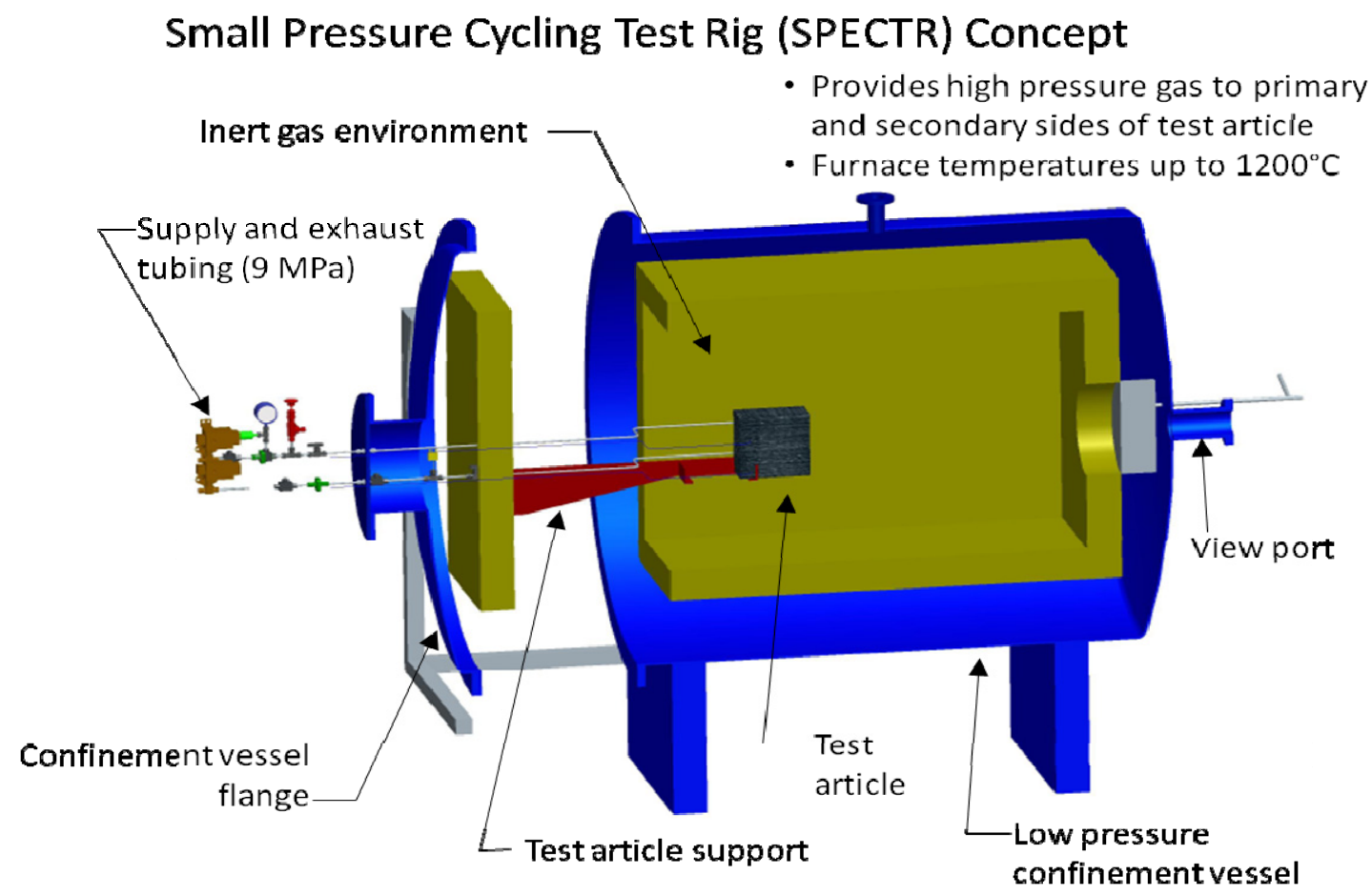

Figure 1. SPECTR furnace concept.

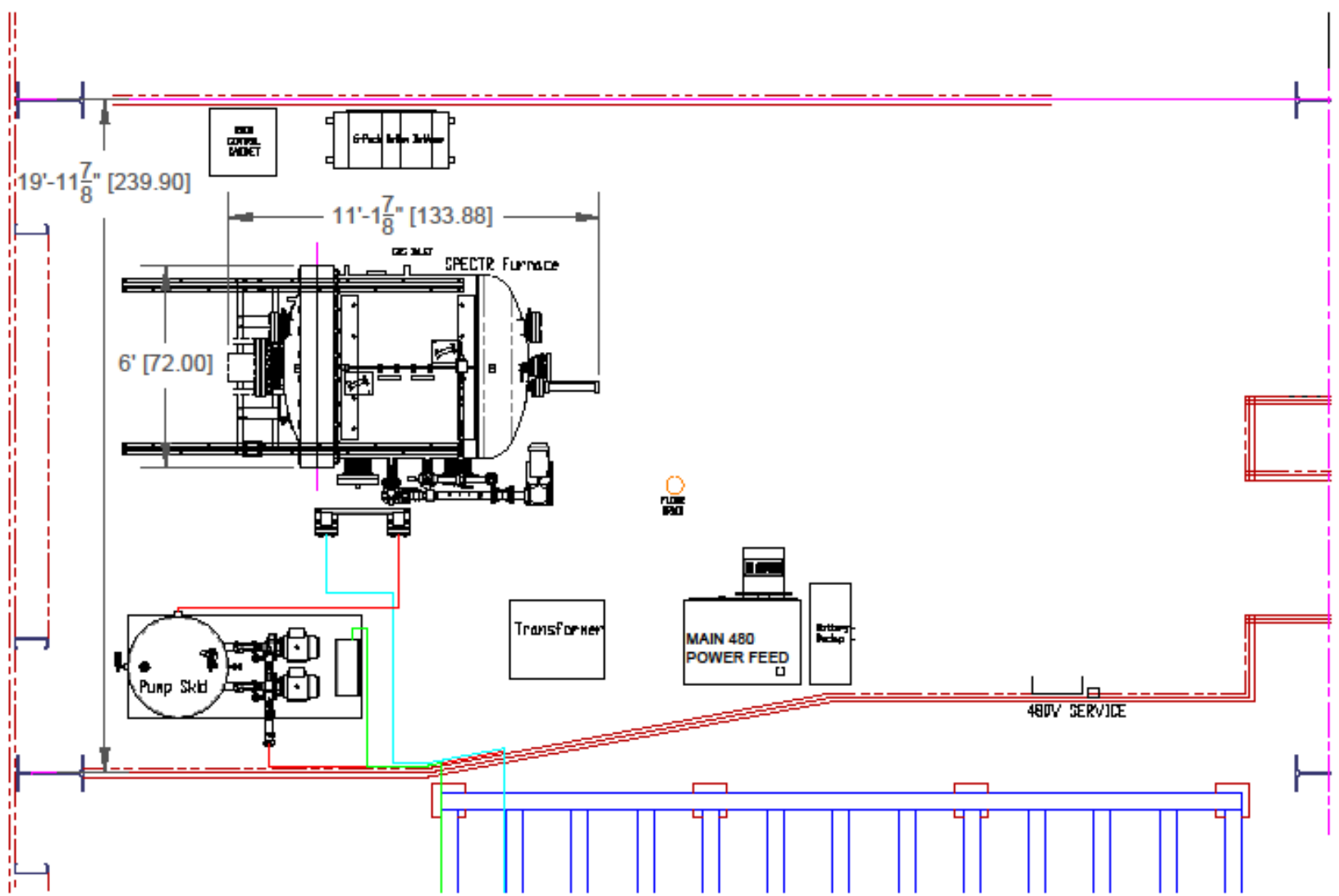

Figure 2. SPECTR Arrangement in IF-657 Bay W3. 


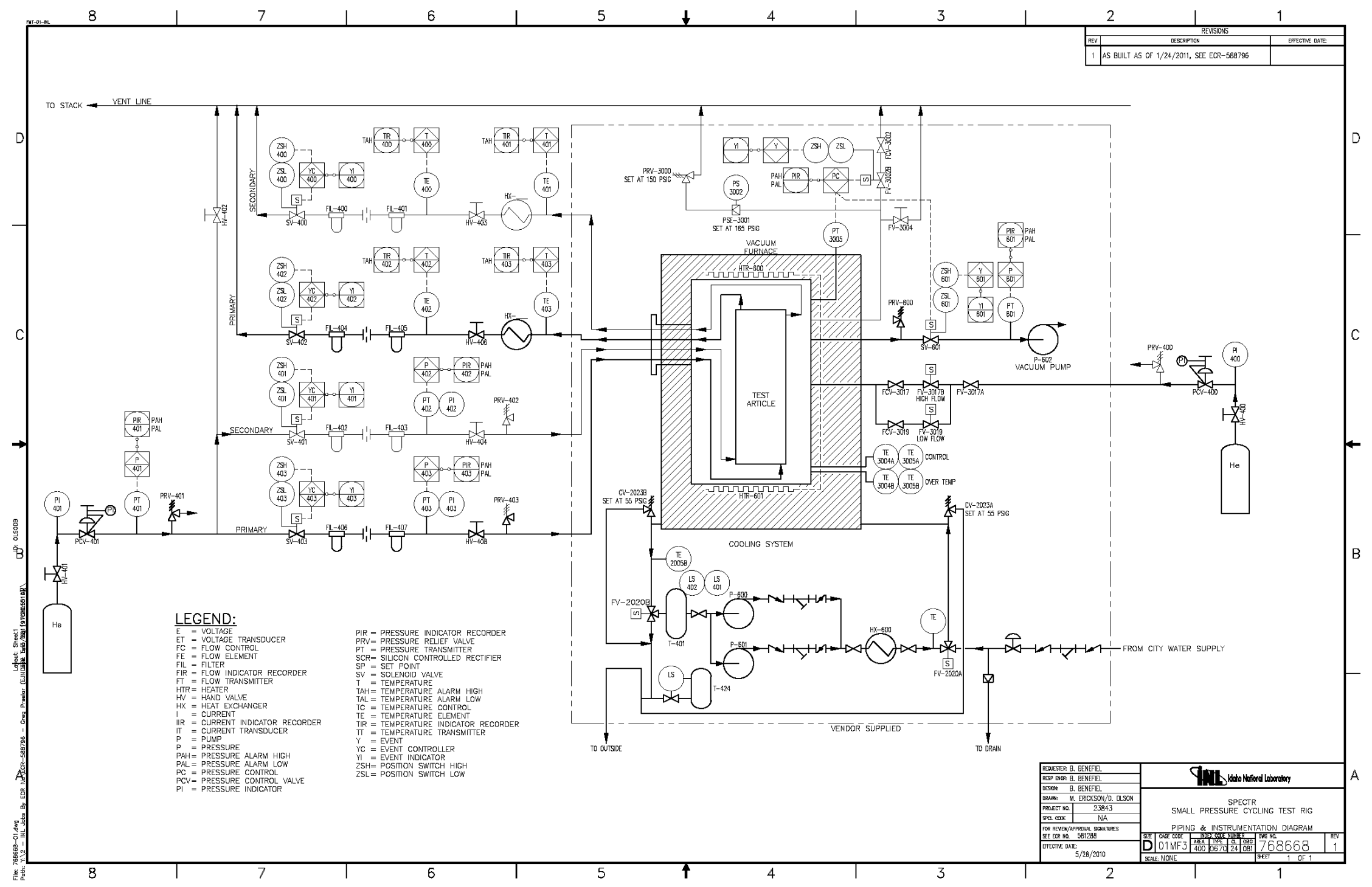

Figure 3. Piping and instrument diagram for the SPECTR system. 
The test article gas supply and exhaust system consists of a gas supply (a bank of helium gas bottles) and two gas supply and exhaust systems. One gas supply and exhaust system is designated the primary side system and the other is designated as the secondary side system, consistent with the terminology used with the IHX. The test article supply and exhaust lines and other penetrations for test instrumentation are made through the flange on the 12 -in pipe diameter nozzle in the vessel head. A variety of penetrations can be accommodated by replacing this flange.

A separate Allen-Bradley PLC, supplied and programmed by INL, controls the gas supplies to and exhausts from the test article. The control system is designed to allow the primary and secondary side pressures to be controlled independently, both in terms of pressure magnitude and time at pressure. The simplest option is to proof test the test article, in which case, the system will pressurize both sides of the test article and maintain that pressure for a set period of time. Fatigue testing can be accomplished by imposing a variety of pressure cycles on the test article. For instance, the primary side and secondary side could be pressurized to different pressures (e.g., $7 \mathrm{MPa}$ on the primary side and $1 \mathrm{MPa}$ on the secondary side). The pressures can be maintained at those values (within a certain control band) for a desired period of time after both sides have reached their setpoints, and then the pressures can be reversed (e.g., $1 \mathrm{MPa}$ on the primary side and $7 \mathrm{MPa}$ on the secondary side). The AVS and INL PLCs communicate with each other to transfer alarm and emergency stop commands between the systems.

\subsection{Operations Overview}

A typical sequence of operation for a test in SPECTR is as follows:

1. The vacuum system evacuates the vessel to less than 10 Torr to remove contaminants. The furnace inert gas supply system then fills the furnace volume with inert gas (typically helium) to a specified pressure.

2. After backfill, the furnace control system parameters are set to maintain a specified heat-up rate as indicated by the two redundant control thermocouples, initiating the heat-up cycle. Current plans are to bring the furnace hot zone to a specified temperature and hold it at that temperature. Temperature transients will not be induced using the furnace because cycling the temperature of the furnace cannot be accomplished quickly. As part of the initial setup of the control system for a given experiment, high temperature setpoints are established. If these high temperature setpoints are reached by either the control thermocouples or the dedicated over-temperature thermocouples, power to the heating elements is reduced to zero.

3. During heat up, the coolant circulation system operates at a constant flow to circulate coolant through the cooling water channels. The air-cooled heat exchanger skid control system operates one or both of the heat exchanger air fans to maintain the return coolant temperature at less than $35^{\circ} \mathrm{C}$. Flow and temperature alarms are provided on the coolant circulation system to warn the operator of a failure in the coolant system.

4. The furnace pressure is ramped up as needed to maintain the system at a specified pressure. Current plans are to maintain the furnace chamber pressure at a constant value of $34 \mathrm{kPa}$ in helium.

5. Gas is supplied to the furnace chamber from a bottle manifold and the excess pressure in the chamber is vented to the atmosphere through a valve. On detection of high pressure (in excess of the high pressure alarm setpoint), the system is vented and the power to the furnace heaters is reduced to zero. Final overpressure protection of the furnace is provided by a rupture disk in series with a pressure relief valve.

6. Once the furnace chamber is at the desired pressure and temperature, the test article gas supply system provides high pressure gas (helium) to the test article. As noted previously, two gas supply lines and two gas exhaust lines are routed through a flange in the head of the furnace vessel. When 
testing an IHX subcomponent, the primary and secondary sides of the test article can be pressurized and depressurized independently. The gas (helium) can be provided to the test article at pressures of up to $7 \mathrm{MPa}$. During the depressurization cycle, the gas is vented to the environment.

The SPECTR system requires an electrical feed of approximately $175 \mathrm{amps}$ at $480 \mathrm{~V}$.

\subsubsection{Work Controls}

The SPECTR system was designed in accordance with the INL Laboratory-wide Procedure (LWP) LWP-10400, "Design Control." The installation and operation of SPECTR is accomplished in accordance with LWP-21220. Work on the SPECTR system is performed in accordance with an approved Laboratory Instruction (LI), LI-1657-11-IEDF. The LI was issued on June 1, 2010.

\subsubsection{Quality Assurance}

In accordance with LWP-13016, “Applying Quality Assurance Requirements to Research and Development Activities," a Quality Level Determination (QLD) was developed (see QLD-REC-000168). This QLD determined that the design, procurement, installation and operation of the SPECTR system was Quality Level (QL) 3. The data from the SO testing were also judged to be QL-3. Separate QLDs will be generated for future test matrices for future experiments to assess the QL based on data use. 


\section{SYSTEM FABRICATION AND INSTALLATION}

SPECTR furnace system was fabricated and completely assembled at the AVS facilities in Ayer, MA. Factory acceptance testing was conducted by AVS personnel and witnessed by INL personnel at the AVS facility on May 10 and 11, 2011. This testing demonstrated that the system could be operated at temperatures up to $1200^{\circ} \mathrm{C}$ in a helium environment of $34 \mathrm{kPa}$, and at temperatures up to $1200^{\circ} \mathrm{C}$ in a nitrogen environment of $1 \mathrm{MPa}$. After testing, the system was disassembled and transported to INL via truck. The system arrived at INL June 17, 2011. The furnace itself was off-loaded and placed in position in Bay W-3 of Building IF-657, also known as the INL Engineering Demonstration Facility (IEDF), using the IEDF 10-ton crane as shown in Figure 4. Other components were off-loaded by fork truck and placed in the same positions (relative to the furnace) they had been in at AVS. Modifications to the IEDF facility to accommodate pipe and electrical routing were completed and the SPECTR piping and electrical connections were reestablished. The installed furnace system is shown in Figures 5 and 6.

The test article gas supply and exhaust system were designed and fabricated at INL. These components are shown in Figure 7. The equipment stand (on the left in Figure 7) contains the valves and instrumentation necessary to supply gas to and exhaust gas from the primary and secondary sides of the test article. The control system is an Allen Bradley PLC.

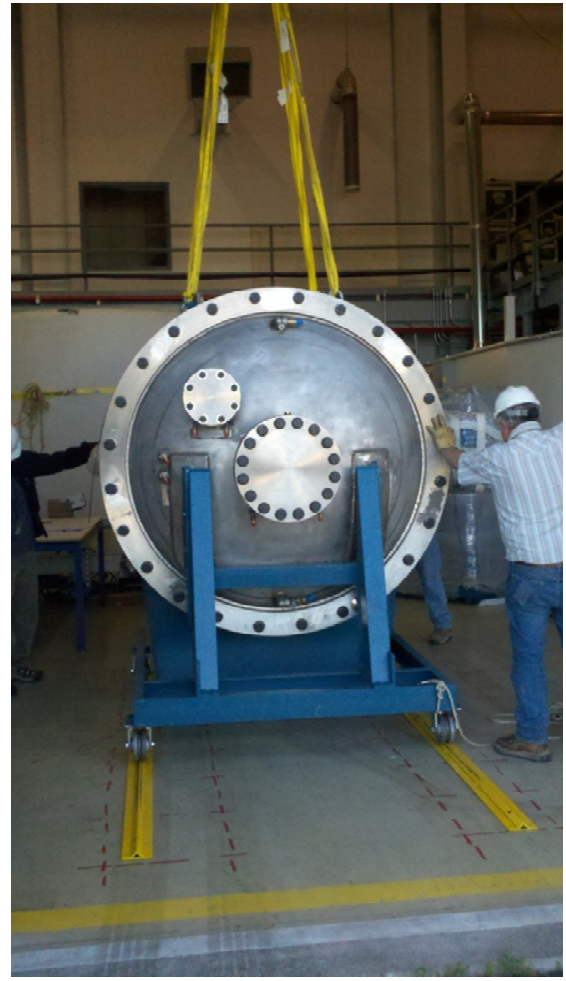

Figure 4. Placing the SPECTR furnace in IEDF Bay 3.

The SPECTR initial check-out and startup testing commenced on July 12, 2011.

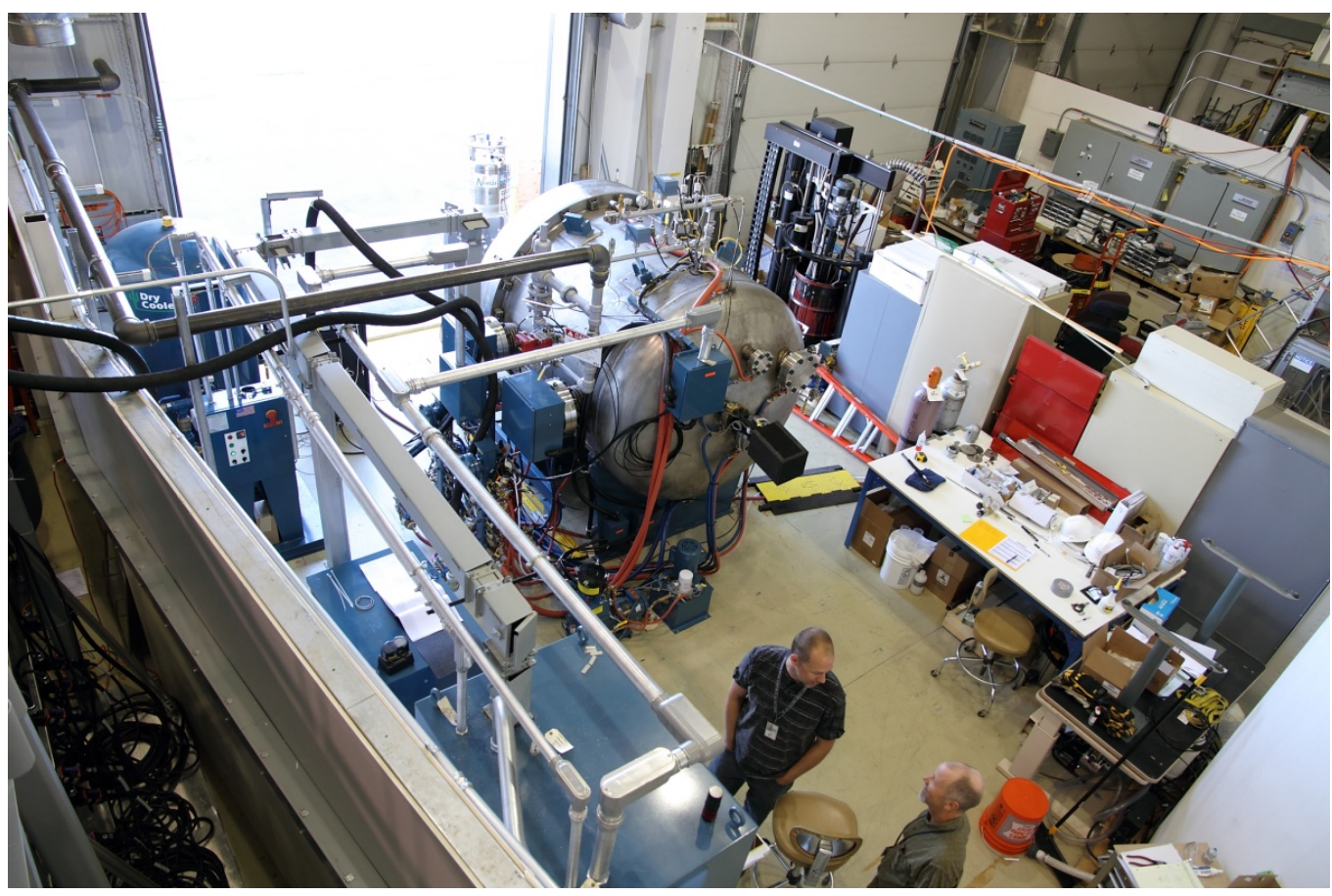

Figure 5. SPECTR system in Bay W-3 of IEDF. 


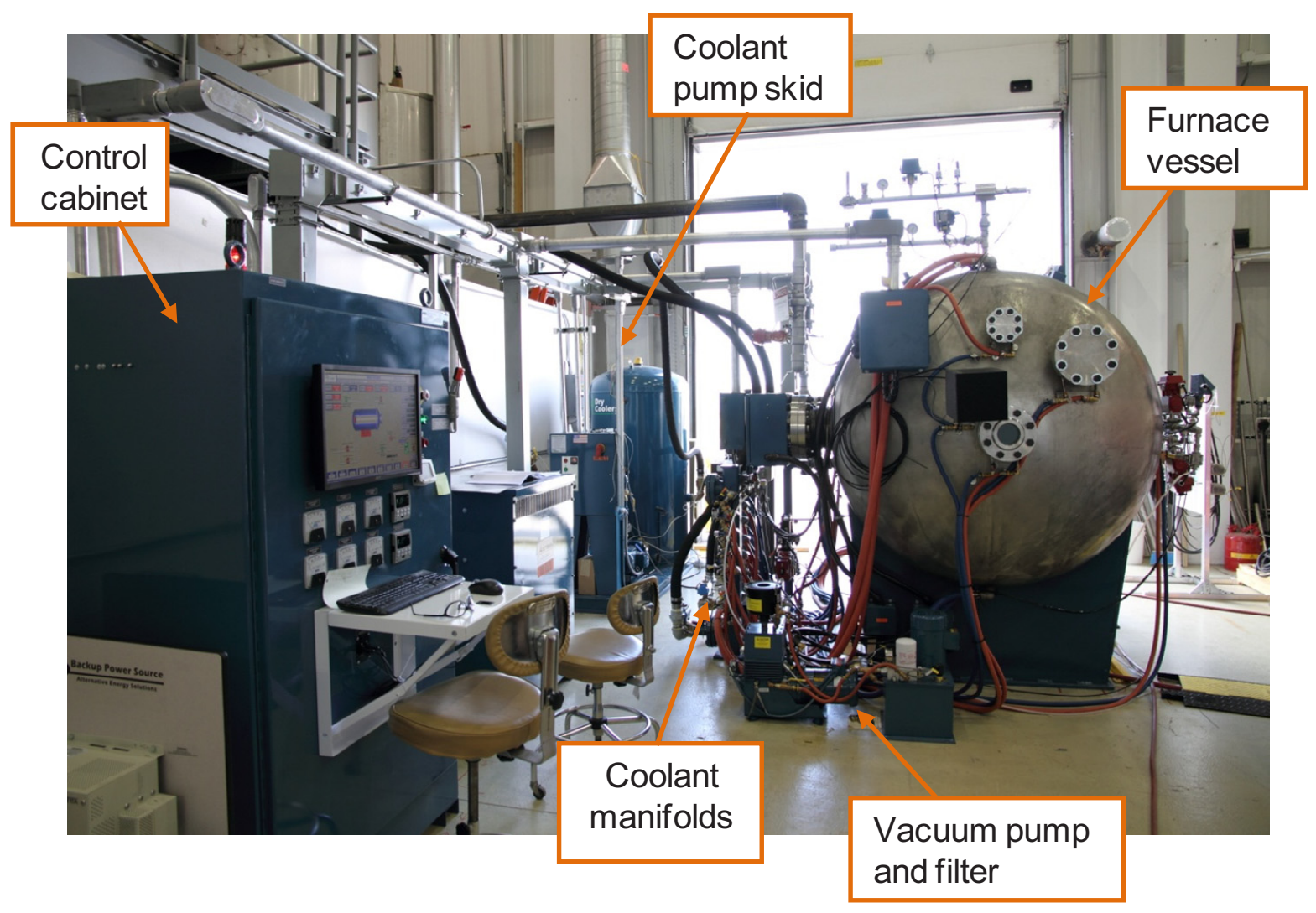

Figure 6. SPECTR system viewed from inside Bay W-3 of IEDF.

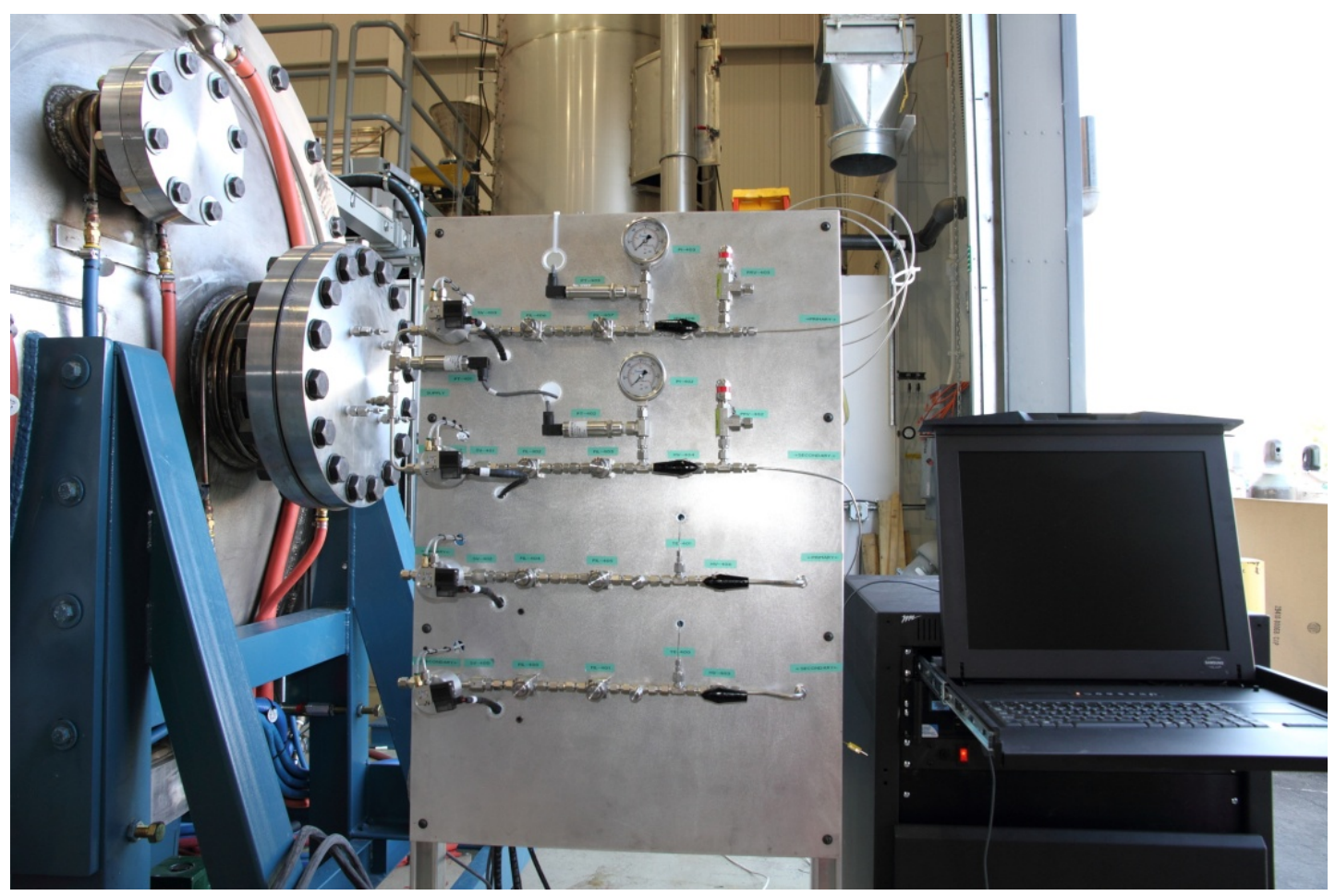

Figure 7. Test article gas supply and exhaust system. 


\section{SYSTEM OPERATIONAL TESTING}

Operation of the vendor-supplied portion of the SPECTR system to the maximum design conditions was demonstrated at the AVS facility in Ayer, MA. The system was then disassembled and shipped to the INL where it was reassembled in Bay W-3 of the IEDF. The SO testing conducted at INL in accordance with PLN-3875 (Landman 2011) was performed to assure that the system was reinstalled properly, the system could still be operated at design conditions, and to verify operation of the INL test article system along with the furnace system. This section overviews the control systems and describes the tests performed. The data that were used to develop the charts in this section will be included with the electronic file of this report.

\subsection{Overview}

The AVS Allen Bradley control system can either be controlled manually or automatically via the various control screens in the human-machine interface (HMI). The main control screen for the HMI is shown in Figure 8. Manual control is implemented by clicking on the various components to turn them on or off.

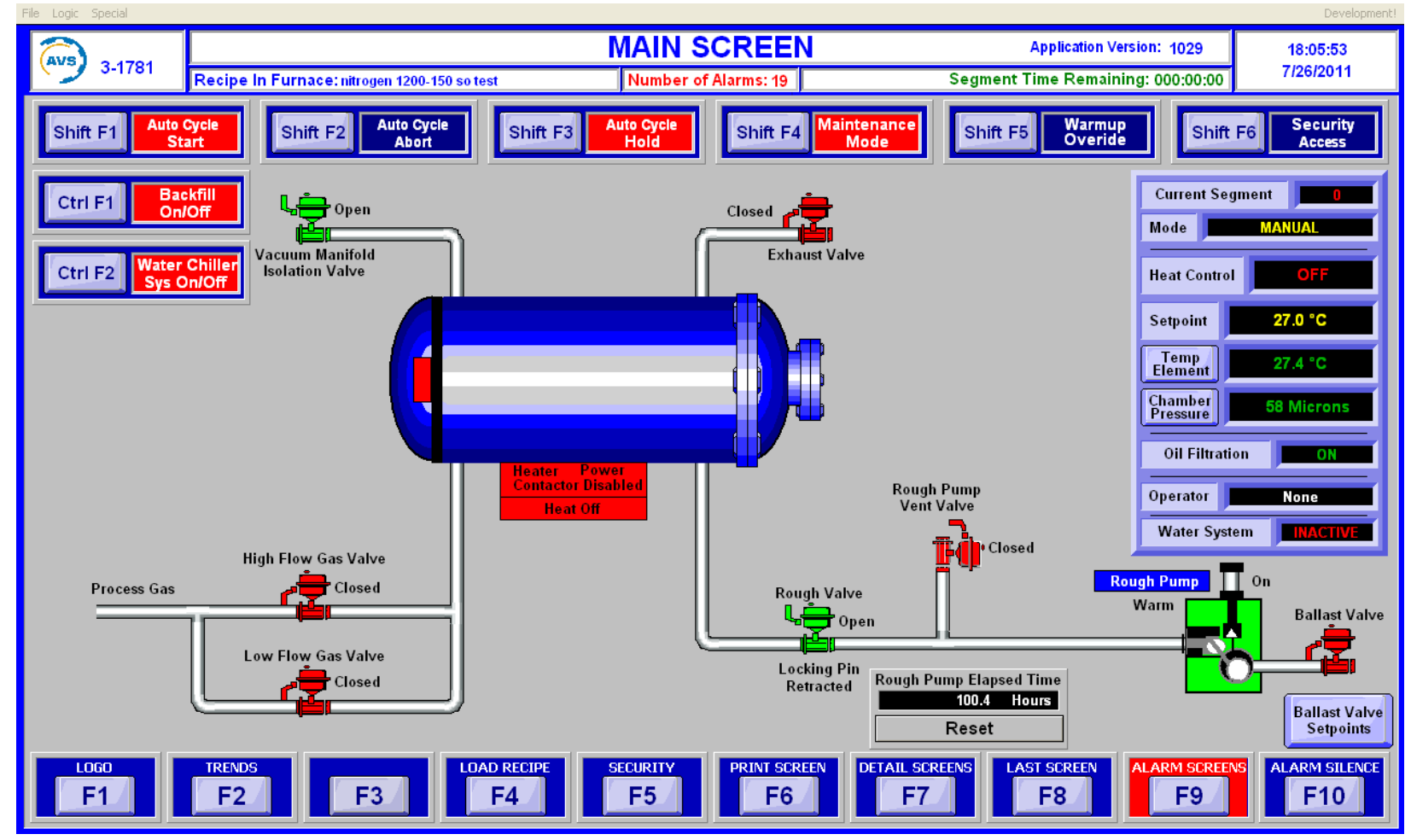

Figure 8. Main control screen for the AVS furnace system.

The functions to be performed by the control system for automatic operation are defined using "recipes," which are a compilation of a series of set functions that have been defined by AVS. By defining the segments within a recipe, a user can set up a sequence of control events. A typical recipe screen is shown in Figure 9. This recipe (for operation of the $600^{\circ} \mathrm{C}, 34 \mathrm{kPa}$ helium test) consists of 16 segments that load the values for the control system tuning, evacuate the vessel, backfill (with helium), ramp the pressure to $14 \mathrm{kPa}$, ramp the temperature to $600^{\circ} \mathrm{C}$, raise the pressure to the final desired value of $34 \mathrm{kPa}$ (if necessary), and then hold the system at the set pressure and temperature until the INL test article system sends a signal indicating that its operation is complete. 


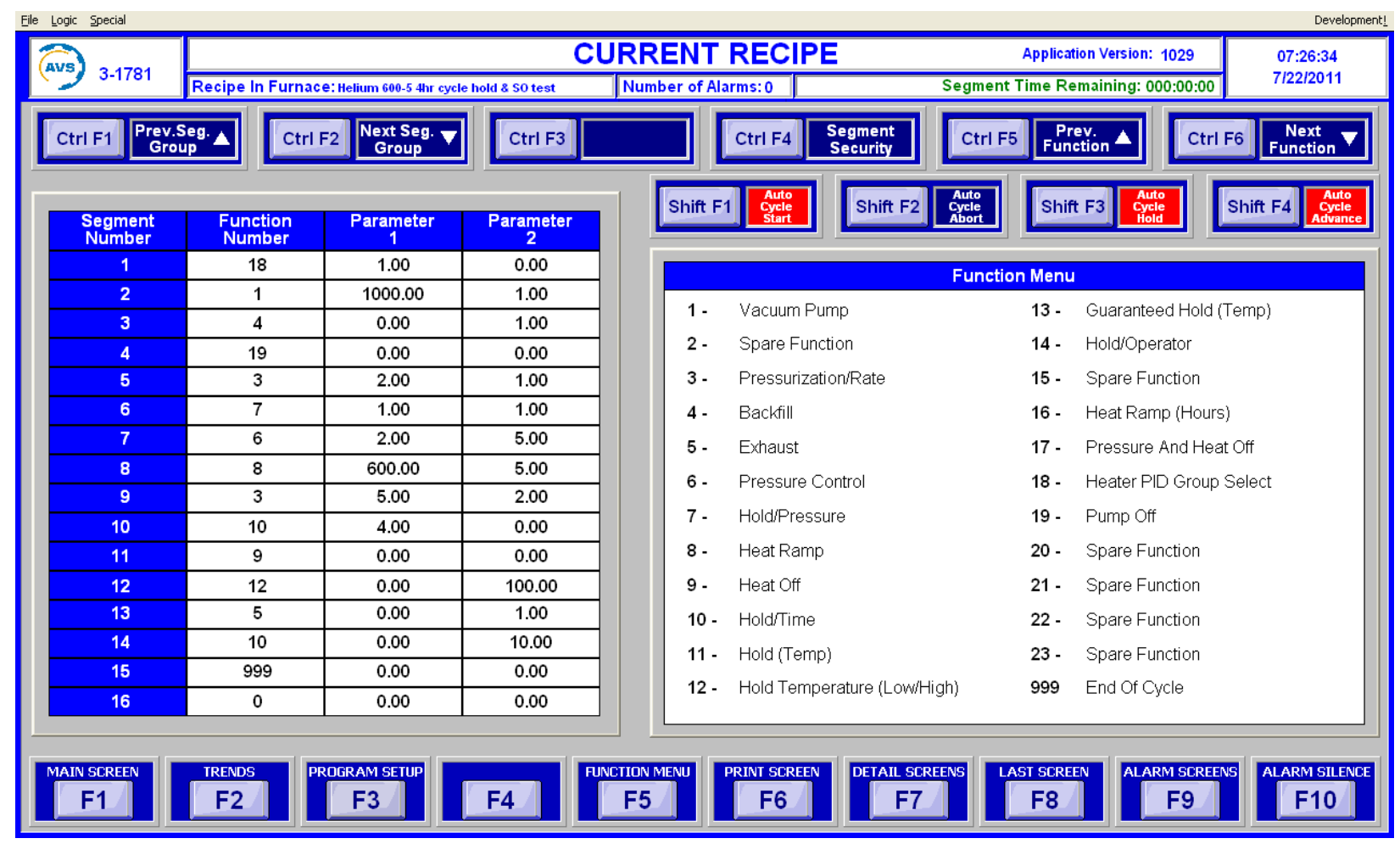

Figure 9. Typical recipe screen from the AVS control system.

The INL test article pressure control system is a separate Allen Bradley system that performs functions not as complex as those of the furnace system so recipes were not required. All the information can be entered or presented on the main control screen shown in Figure 10. As noted previously, the system is designed to pressurize and depressurize the primary and secondary sides of the test article (in this case, two separate lengths of tubing). The pressures for the high and low cycles, the hold times for the cycles, and the number of cycles to be performed are entered in the input area (lower left on the screen). The control bands (plus and minus dead bands) are also entered in this area. The lower right portion of the screen presents the recent pressure traces. As can be seen in Figure 10, the primary and secondary pressures are being cycled alternately.

The system status is shown in the upper half of the screen. The lines representing the supply and exhaust tubing change colors to indicate the status, red being "Off" and green being "On." Supply pressure is available to the inlet valves for the primary and secondary systems, as indicated by the green lines in Figure 10. The system is currently holding for a pressure cycle so the supply and exhaust lines for both the primary and secondary are red. When the valve positions change, the lines will change color accordingly.

\subsection{Safety Interlocks and Alarm Testing}

Conditions, such as loss of coolant flow, overtemperature, and overpressure, will result in alarms and automatic actions in the furnace system. These alarms and automatic actions were induced by setting the alarm setpoints at unusually low values or deliberately stopping equipment (in the case of the water circulation system). The proper responses were then verified. All interlocks were determined to be operating properly. 


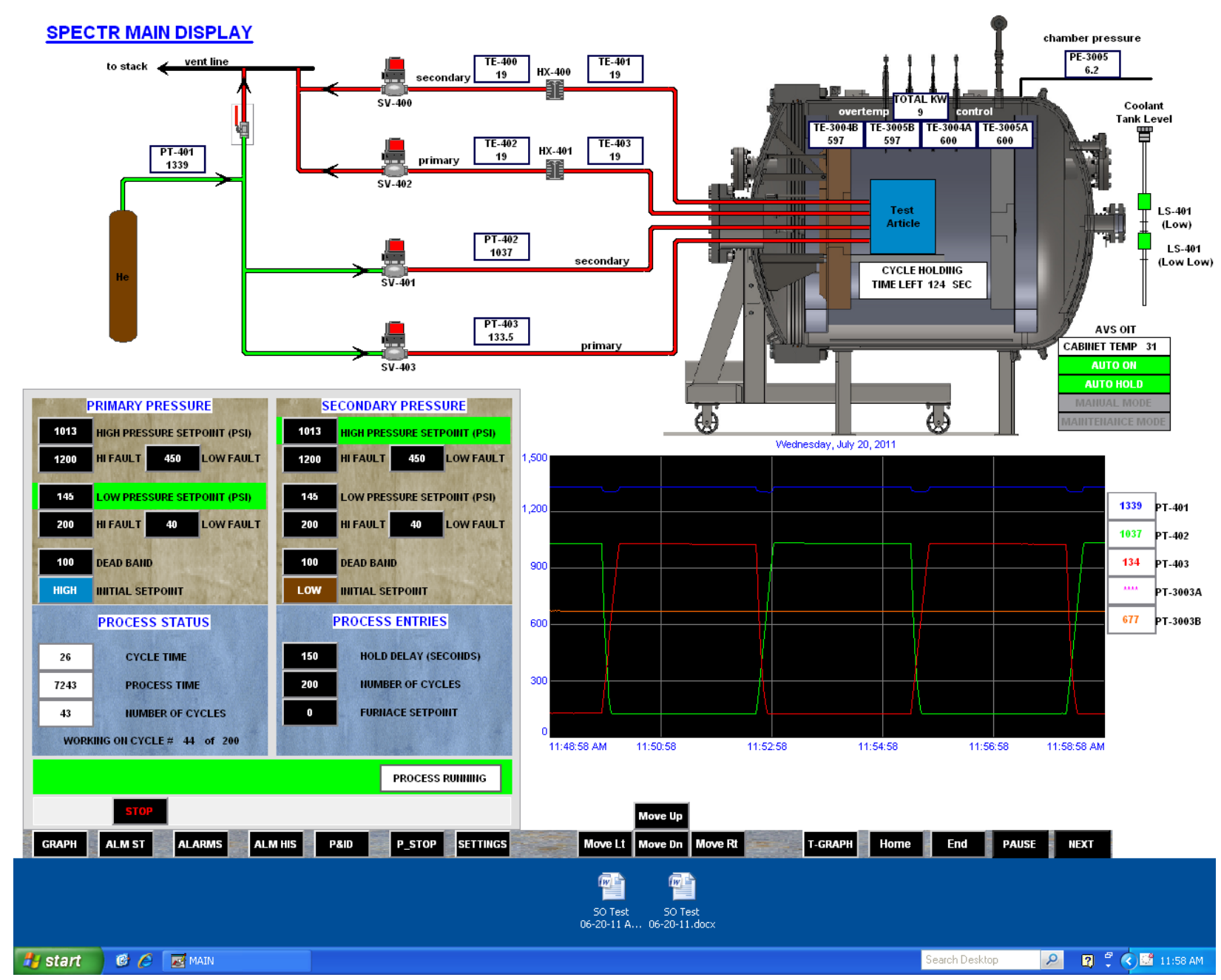

Figure 10. Main display screen for test article control system.

\subsection{Testing at Design Conditions in Helium}

A PLC recipe was developed to demonstrate the vessel evacuation and pressure and temperature control from near ambient temperatures to the design conditions of $34 \mathrm{kPa}$ of helium and $1200^{\circ} \mathrm{C}$. The testing was conducted on July 18, 2011. A screen capture of the trend displaying the results of this test is shown in Figure 11. For clarity, and to make it easier to add further notations, the data from the HMI was imported into Excel and the results displayed as a chart in Figure 12. For discussions on the subsequent tests, only the Excel file is shown. These data will be filed with the electronic version of this report.

During the $1200^{\circ} \mathrm{C}$ hold, there was a spike in the temperature caused by changing the thermocouple that was being used to control the furnace. As shown in Figure 13, the thermocouple designated as "in control" of the furnace heaters was noted to be reading lower than the other thermocouples. The system operator changed the control thermocouple to the redundant thermocouple (there are two control thermocouples and two overtemperature thermocouples); the redundant thermocouple was reading a higher temperature, thus perturbing the heater power. It was later determined that the proximity of the thermocouple to the heater element was the likely cause of this low reading and the position of the heater element was adjusted. The readings from the thermocouples showed much better agreement in later runs. 


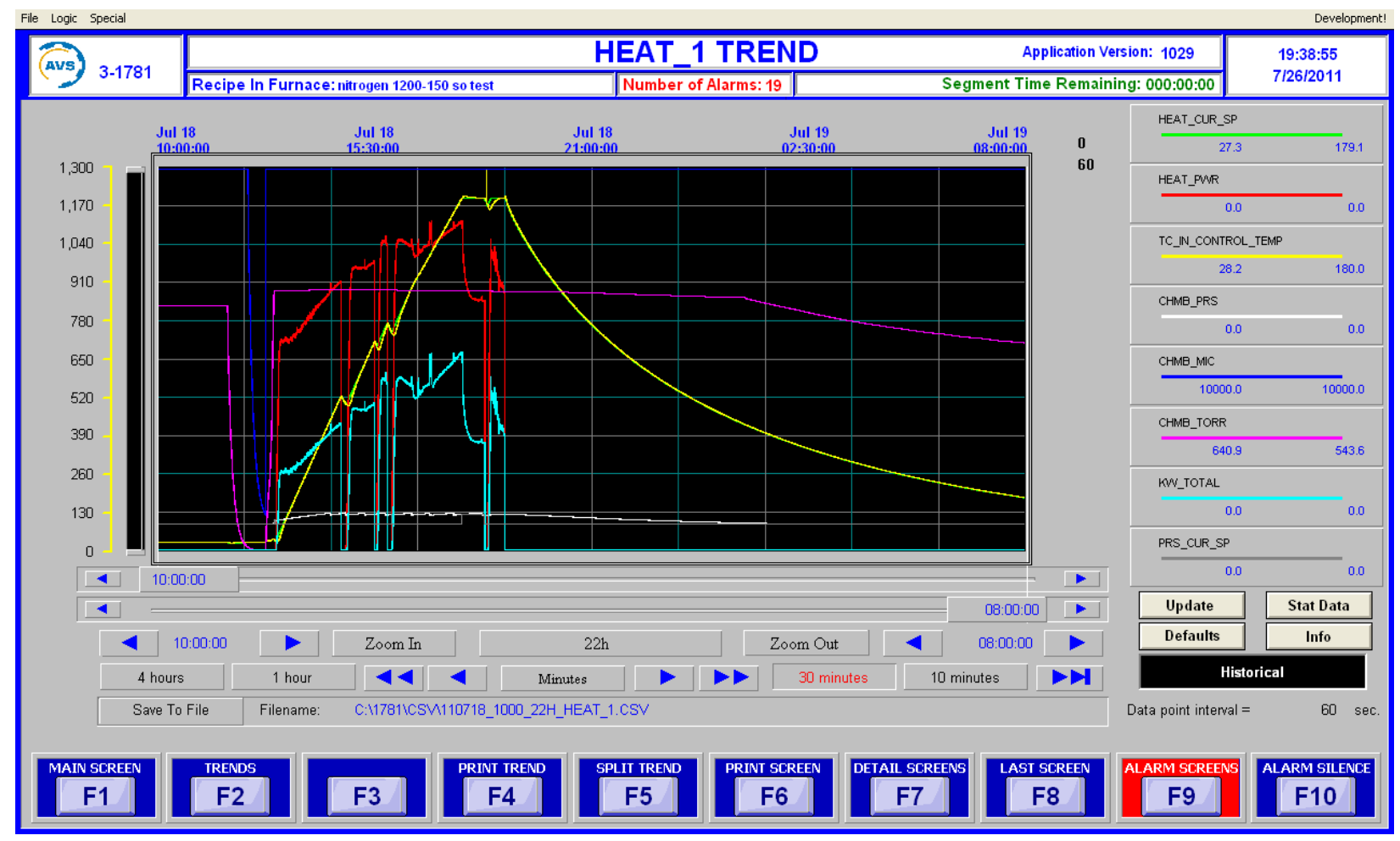

Figure 11. Screen capture from $1200^{\circ} \mathrm{C}, 34 \mathrm{kPa}$ helium demonstration run.

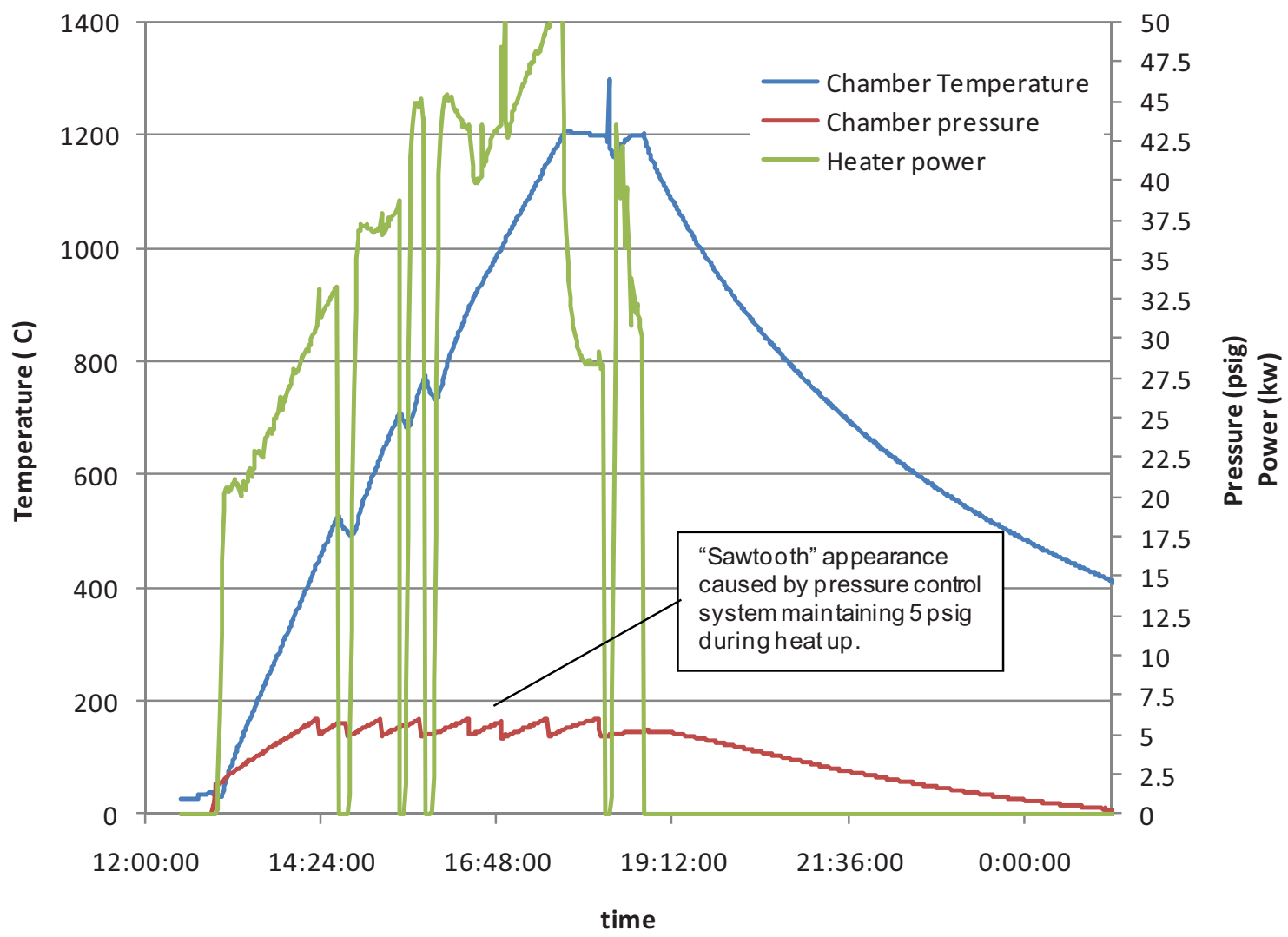

Figure 12. Data from $1200^{\circ} \mathrm{C}, 34 \mathrm{kPa}$ helium demonstration run. 


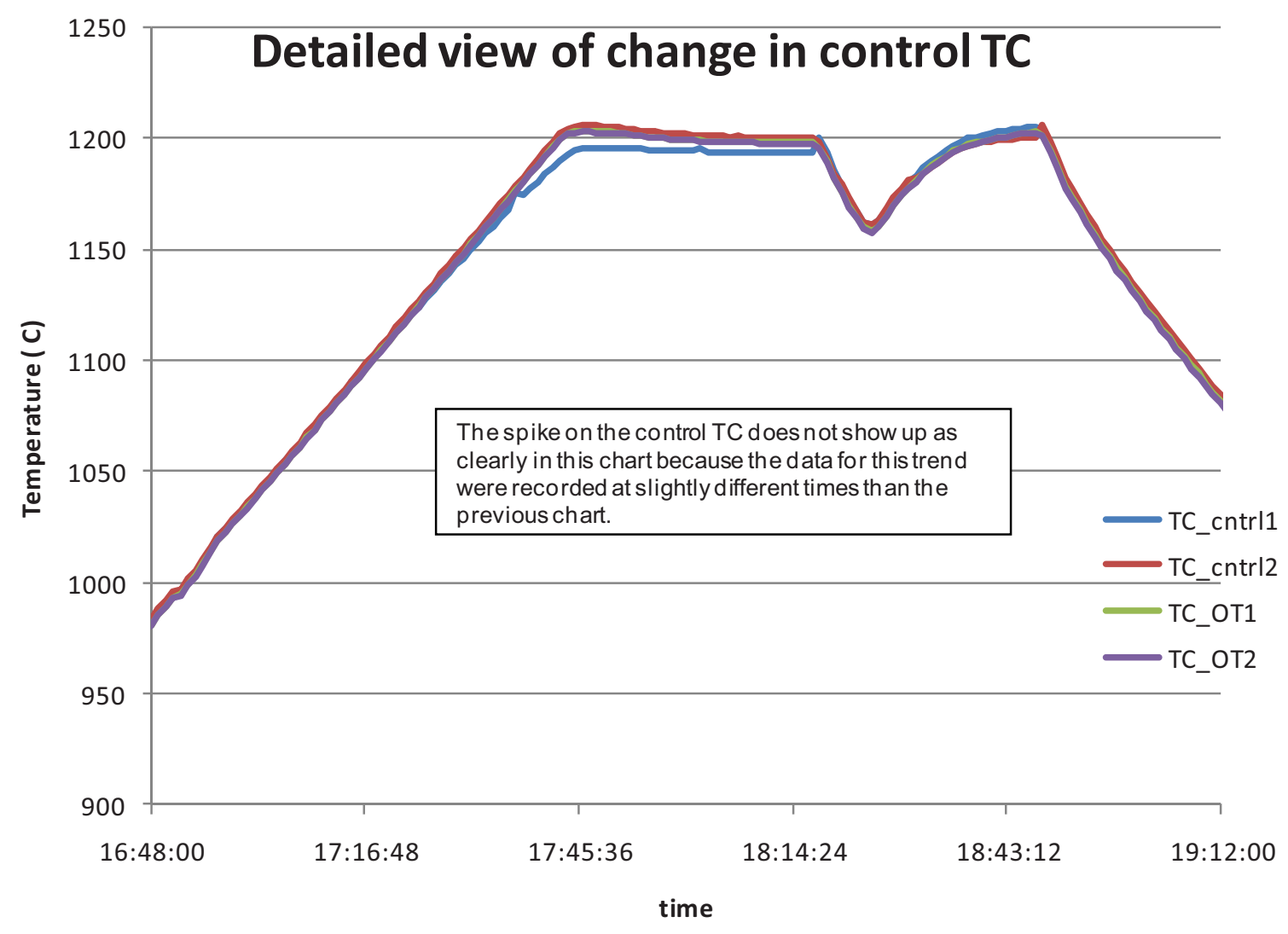

Figure 13. View of system response when the control thermocouple was changed.

\subsection{Testing at Design Conditions in Nitrogen}

The PLC recipe developed for this test to the design conditions of $1 \mathrm{MPa}$ of nitrogen and $1200^{\circ} \mathrm{C}$ was similar to that of the $1200^{\circ} \mathrm{C} 34 \mathrm{kPa}$ helium test. This testing was conducted on July 27, 2011. After evacuation to remove the contaminants, the system was pressurized to $0.34 \mathrm{MPa}$ and the heaters were energized to start a heatup of $5^{\circ} \mathrm{C}$ per minute. As the furnace temperature increased, the pressure increased.

The data from this test are shown in Figure 14. The factory acceptance test performed in Ayer, MA showed that the system was capable of maintaining the design conditions of $1200^{\circ} \mathrm{C}$ and $1 \mathrm{MPa}$, but the INL installation did not. As shown in Figure 14, even though the heaters were operating at $100 \%$ power, they were only able to raise the temperature in the furnace to slightly over $1100^{\circ} \mathrm{C}$ at $1 \mathrm{MPa}$. After verifying that all the thermocouples were providing consistent output, the team decided to reduce the pressure in the vessel. The pressure was reduced to about $0.75 \mathrm{MPa}$ and the heaters were demonstrated to be able to maintain $1200^{\circ} \mathrm{C}$ at about $93 \%$ power. 


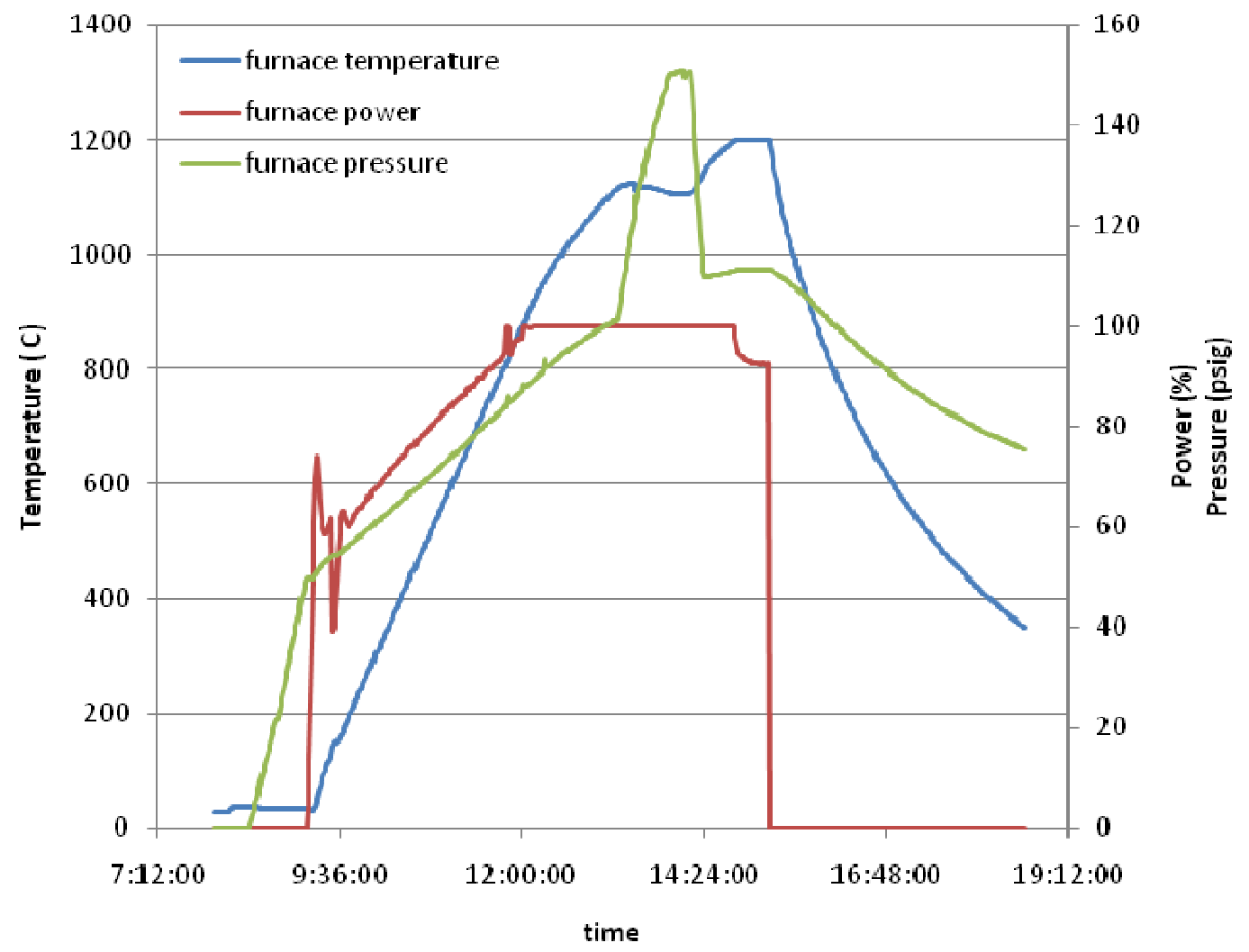

Figure 14. Data from $1200^{\circ} \mathrm{C}, 1 \mathrm{MPa}$ nitrogen demonstration run.

When the furnace reached about $1000^{\circ} \mathrm{C}$, the view port in the back of the pressure vessel was opened to view the interior of the hot zone. Photographs of the view port are shown in Figure 15.
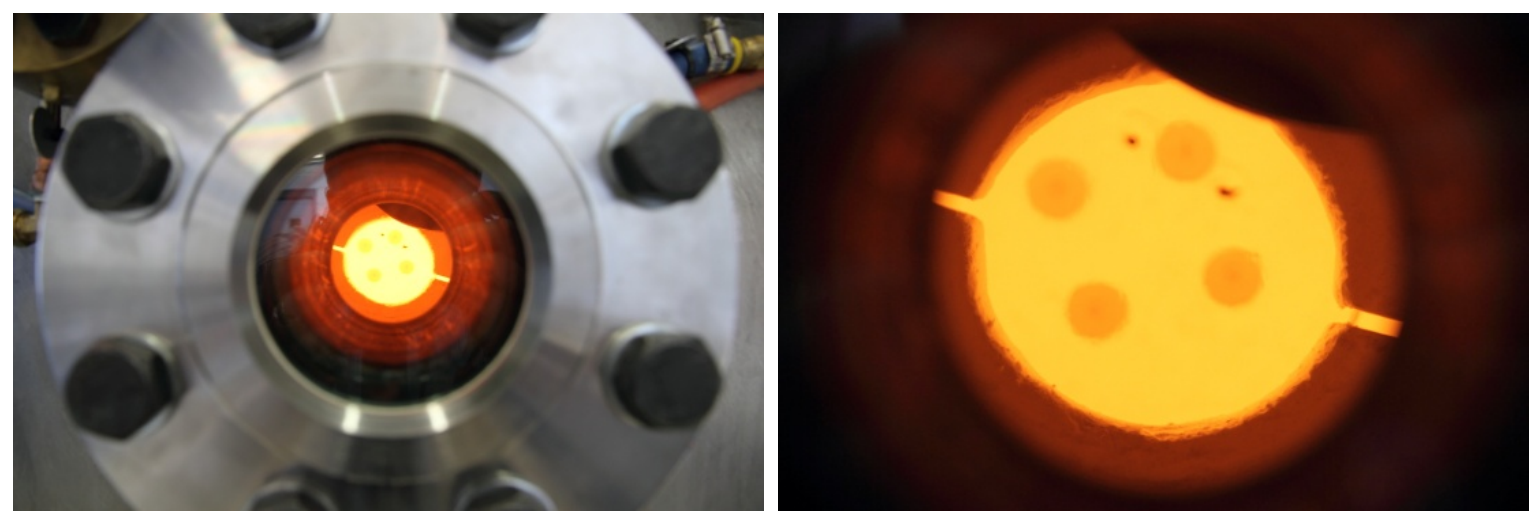

Figure 15. Photographs looking into the view port at $1000^{\circ} \mathrm{C}$.

\subsection{Testing of SPECTR with Test Article}

A simulated test article (two lengths of stainless steel 0.125 inch OD by 0.035 inch wall tubing) was installed in the furnace. One tube was connected to the primary side of the test article gas supply and exhaust system and the other was connected to the secondary side of the test article gas supply and exhaust system. The PLC recipe used for this test is shown in Figure 16. The testing was performed on July 21, 2011. 


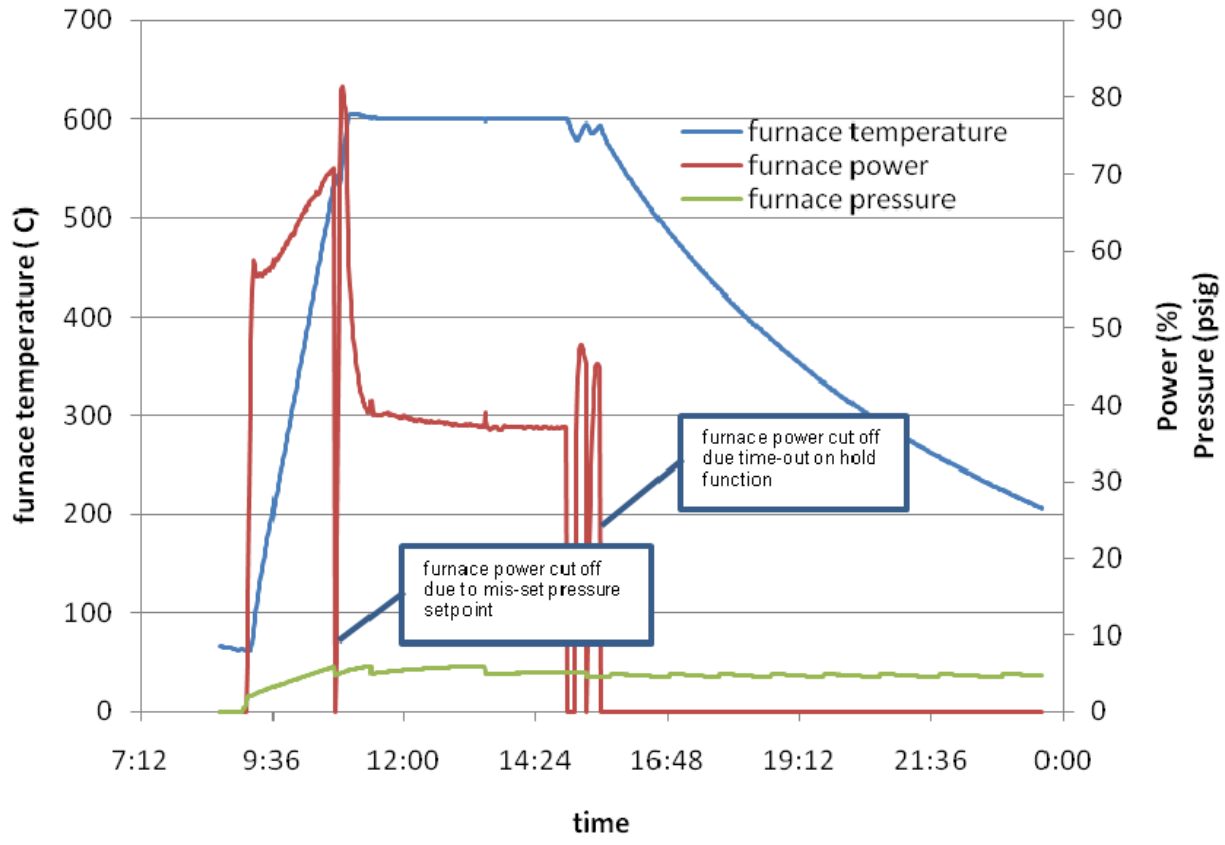

Figure 16. Furnace operation during $34 \mathrm{kPa}, 600^{\circ} \mathrm{C} \mathrm{SO}$ test with test article.

Initially, communications between the INL and AVS control systems were tested and debugged. The furnace control system recipe was started and the system advanced to $34 \mathrm{kPa}$ and $600^{\circ} \mathrm{C}$ as shown in Figure 16. When the furnace system reached the specified conditions, the test article system was started. The pressures on the primary and secondary systems were alternated between nominally 7 and $1 \mathrm{MPa}$, with the primary side starting the cycle high. The demonstration consisted of 100 complete cycles (high and low pressure). A typical pressure trace from the start of the run is shown in Figure 17.

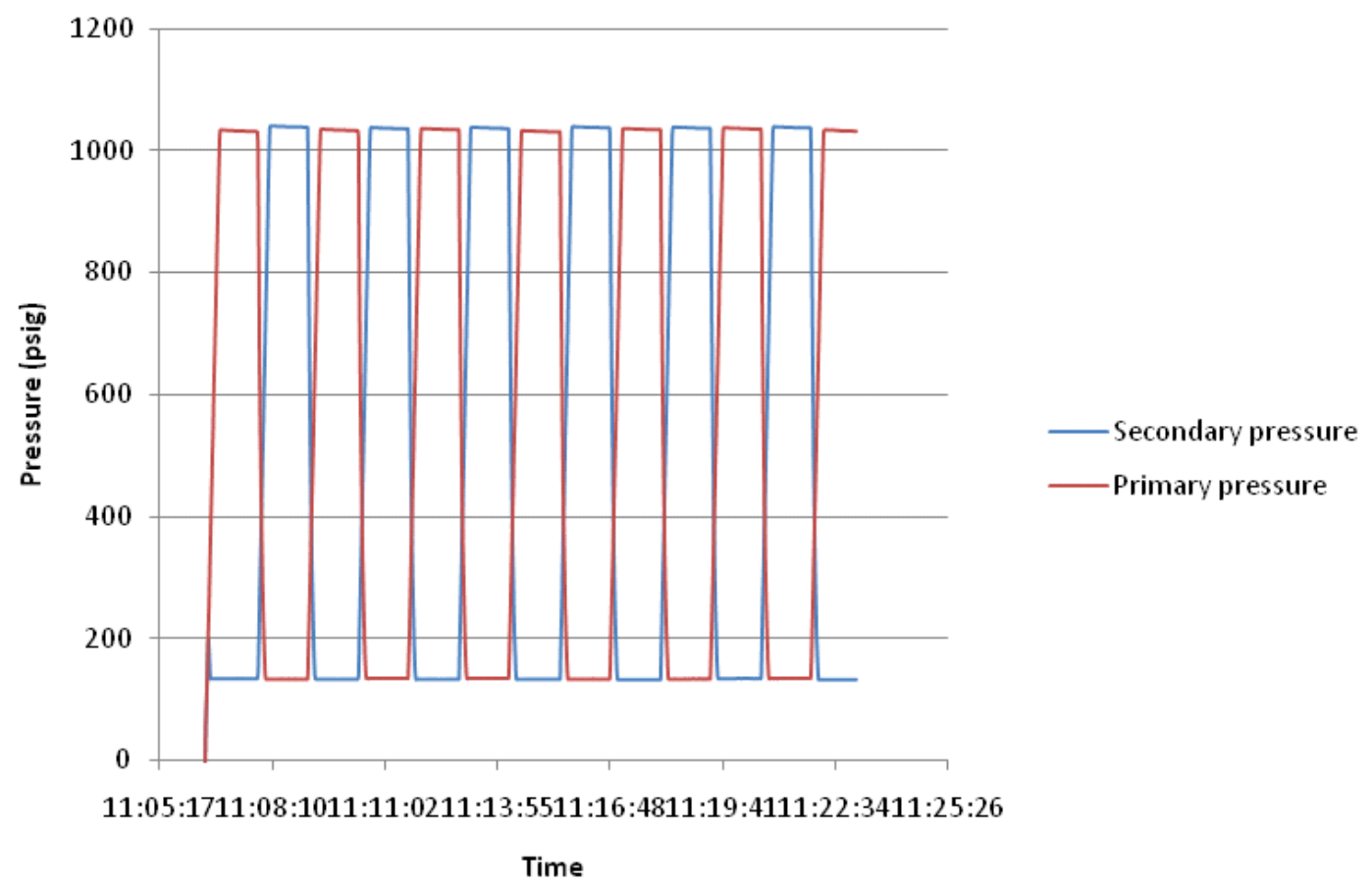

Figure 17. Plot of test article pressure cycling. 


\subsection{Limitations of the SO Test}

Generally, the furnace system performed very well, but there were some features that could not be tested or were not met completely.

1. The system specification requires that the rails be capable of supporting a test article weighing up to $150 \mathrm{lbf}$. The rails that were initially tested by the furnace system supplier failed and new rails, made of a higher grade of silicon carbide, were ordered. The rails had not arrived in time for the SO test and will be tested separately. This component does not have an impact on the furnace functionality.

2. As noted in the discussion on the $1200^{\circ} \mathrm{C} 1 \mathrm{MPa}$ nitrogen test, the system was unable to meet the design conditions, even though it was demonstrated at the factory. The reason for this difference between the factory test and INL test are still being evaluated. However, there are two reasons why this failure to meet the design requirement is acceptable. First, the requirement for operation at $1200^{\circ} \mathrm{C}$ and $150 \mathrm{psig}$ of nitrogen exceeds the anticipated need for testing components for the NGNP. Second, if there is a need for operation in an inert environment at $1200^{\circ} \mathrm{C}$ and $150 \mathrm{psig}$, it is likely that argon (with a lower thermal conductivity than nitrogen) could be used and $1200^{\circ} \mathrm{C}$ achieved.

The INL test article pressurization system worked well and met its design requirements. 


\section{POTENTIAL FUTURE USES}

The SPECTR system fills a niche in the suite of testing capabilities being used to advance the TRLs for the NGNP heat transport system. Figure 18 depicts the progression from TRL-3 (proof of concept) to TRL-4 (bench scale). The fabrication methods currently being considered include using:

- Diffusion bonding (welding) to assemble the plates of the compact heat exchanger subassemblies

- Dissimilar metal welds in applications such as the steam generator tubes, in which higher temperature materials to be used in the superheater section are welded to the lower temperature materials in the evaporator and preheater sections

- High temperature brazing in the heat exchangers or other process applications.

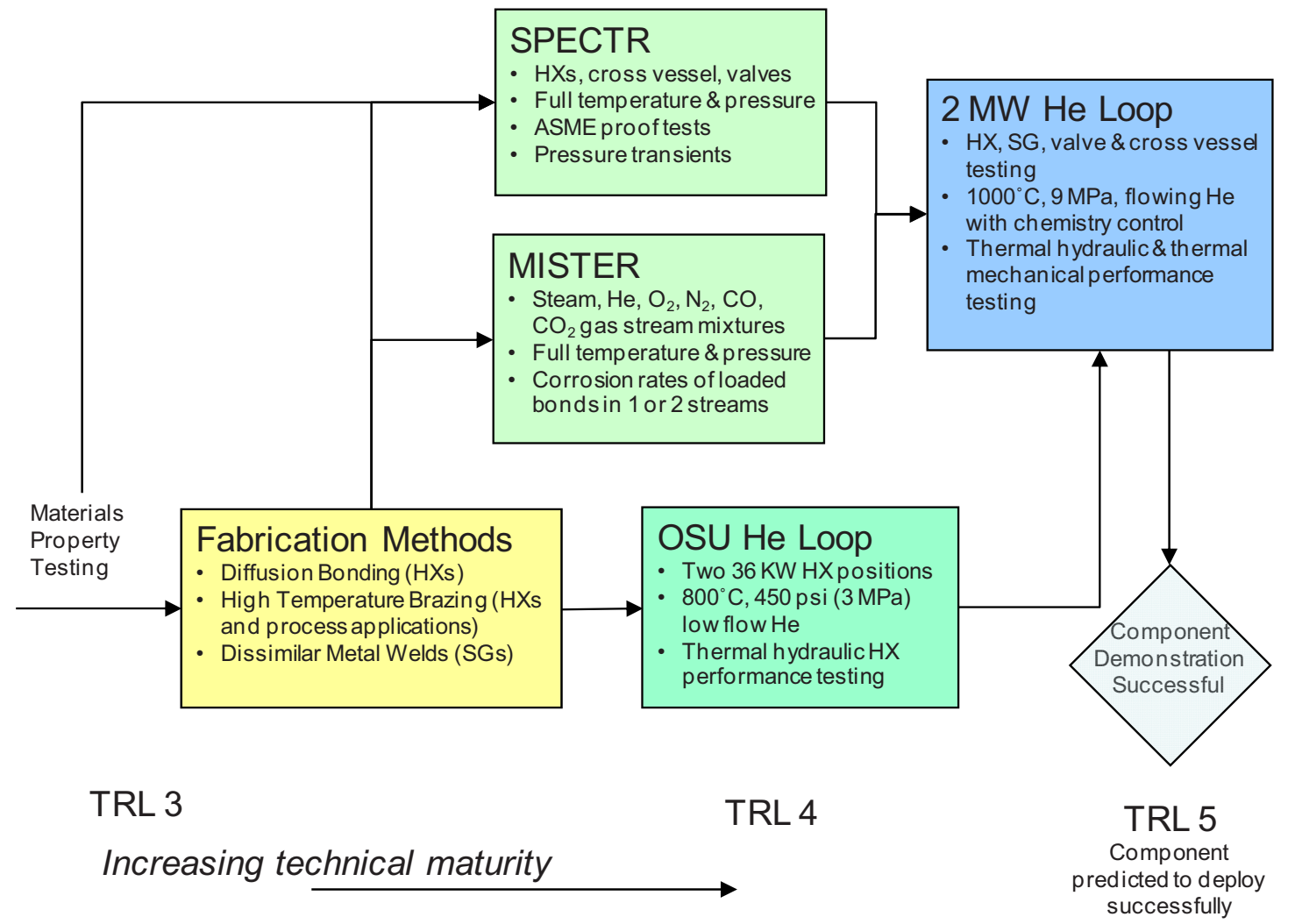

Figure 18. Progression of NGNP heat transport system from TRL-3 (proof of concept) to TRL-4 (bench scale).

SPECTR's primary purpose is to support the development of the diffusion bonding fabrication technique. The pressure cycling of the SPECTR system will provide fatigue data on these joints in the heat exchanger subassemblies. SPECTR can also be used in a number of other applications that require high temperatures and pressurized environments such as:

- Testing the structural characteristics of other heat exchanger designs, such as ceramic heat exchangers. The ceramic heat exchangers, like the metallic ones for which SPECTR was designed, are constructed of plates that have very small flow passages in them. The plates are typically bonded in stacks, so the joints between the plates could be tested using the pressure cycling capability. The ceramic heat exchanger also requires, at some point, a joint between the ceramic material and the (usually) metallic materials in the rest of the system. The performance of the ceramic to metallic joint could also be subjected to the pressure cycles. 
- ASME Section III high temperature design data development. As mentioned previously and discussed in Reference 3, SPECTR can be used to test the pressure capsule and the simplified model test devices that have been proposed. The pressure capsule concept, in particular, is very well suited for the SPECTR system. The test specimen consists of a cylinder in which the walls in the central portion of the cylinder are very thin. This central section is placed in a state of biaxial stress (hoop and longitudinal) by the gas pressure applied to the inside of the cylinder. New models for the creep behavior of the specimen can be evaluated by maintaining the specified pressure at elevated temperatures for a relatively long period of time. SPECTR is of sufficient size that several test specimens (operating at different pressures and the same temperature) can be tested in one run.

- High temperature steam electrolysis cell performance testing. The high temperature cells, which are supplied with steam and electrical power, generate hydrogen and oxygen. The current testing of these cells is being performed at $950^{\circ} \mathrm{C}$ and atmospheric pressure. The cells are expected to perform better at higher pressures at the same temperature and SPECTR could be used to subject the cells to ambient pressure of up to $1 \mathrm{MPa}$ at $950^{\circ} \mathrm{C}$, thereby providing an additional data point on the performance curve. Testing of these cells would require new support systems to provide the steam and power and modifications to the test bay to support testing with hydrogen.

- Combined corrosion and creep testing. With the addition of a flow circulation loop on the gas supply to the SPECTR test article, corrosion of material can be examined in heat exchanger or other equipment subassemblies. The physical configuration of the subassemblies may be such that the corrosion rates would be different (e.g., in zones of low flow or recirculation) than for simple test specimens. 


\section{CONCLUSIONS}

The SPECTR SO test was designed to exercise the furnace and test article systems over the range of expected operation and to demonstrate operation at the maximum design requirements. Successful demonstration of the safety interlocks and communications systems was accomplished, as was operation of the furnace at $1200^{\circ} \mathrm{C}$ and $5 \mathrm{psig}$ helium and operation of the combined furnace system and test article pressurization control system. Operation at maximum design conditions of $1200^{\circ} \mathrm{C}$ and $150 \mathrm{psig}$ nitrogen was unsuccessful, in that the heaters could only maintain $1100^{\circ} \mathrm{C}$ at $100 \%$ power. However, reduction of the pressure to $110 \mathrm{psig}$ allowed the furnace system to achieve $1200^{\circ} \mathrm{C}$ at about $93 \%$ power. This inability to maintain $1200^{\circ} \mathrm{C}$ and $150 \mathrm{psig}$ nitrogen is not considered critical because the requirement for operation at $1200^{\circ} \mathrm{C}$ and $150 \mathrm{psig}$ of nitrogen exceeds the anticipated need for testing components for the Next Generation Nuclear Plant and, if there is a need for operation in an inert environment at $1200^{\circ} \mathrm{C}$ and $150 \mathrm{psig}$, it is likely that argon (with a lower thermal conductivity than nitrogen) could be used and $1200^{\circ} \mathrm{C}$ achieved.

In conclusion, the AVS furnace system works well and is well suited for testing at temperatures expected of the current $\left(750^{\circ} \mathrm{C}\right)$ or even the advanced $\left(950^{\circ} \mathrm{C}\right)$ NGNP concepts. The test article gas supply and exhaust system also worked well and successfully cycled a simulated test article for over 100 cycles. The SPECTR system provides a vehicle for performing fatigue testing of NGNP heat exchanger components over the complete range of anticipated operating and upset conditions and can maintain relatively large test articles at temperatures up to $1200^{\circ} \mathrm{C}$ and provide gas to these test articles for fatigue testing, development of creep design data, and a variety of other applications. 


\section{REFERENCES}

Collins, J. W., 2009, "Next Generation Nuclear Plant Project Technology Development Roadmaps: The Technical Path Forward", INL/EXT-08-15148, January 2009.

Mizia, R. E., Scoping Investigation of Diffusion Bonding for NGNP Process Application Heat Exchangers, PLN-3565, July 9, 2010.

Wright, J. K., NGNP Heat Transport System Components Engineering Test Plan, PLN-3305, Rev. 1, June $30,2010$.

Landman, W. H., NGNP Process Heat Applications Small Pressure Cycling Test Rig, TFR-696, April 10, 2010.

Landman, W. H., System Operational Test Plan for SPECTR, PLN-3875, July 6, 2011. 